\title{
The Economics and Politics of Social Democracy: A Reconsideration*
}

\author{
Servaas Storm ${ }^{\dagger}$
}

\section{Working Paper No. 122}

April 27, 2020

\begin{abstract}
Questions about the decline of Social democracy continue to excite wide interest, even in the era of Covid-19. This paper takes a fresh look at topic. It argues that social democratic politics faces a fundamental dilemma: short-term practical relevance requires it to accept, at least partly, the very socio-economic conditions which it purports to change in the longer run. Bhaduri's (1993) essay which analyzes social democracy's attempts to navigate this dilemma by means of 'a nationalization of consumption' and Keynesian demand management, was written before the rise of New ('Third Way') Labor and before the Great Financial Crisis of 2007-8. This paper provides an update, arguing that New Labor's attempt to rescue 'welfare capitalism' entailed a new solution to the dilemma facing social democracy based on an expansion of employment, i.e. an all-out emphasis on "jobs, jobs, jobs". The flip-side (or social cost) of the emphasis on job growth has been a stagnation of productivity growth - which, in turn, has put the "welfare state' under increasing pressure of fiscal austerity. The popular discontent and rise of 'populist' political parties is closely related to the failure of New Labor to navigate social democracy's dilemma.
\end{abstract}

JEL Codes: E6, E10, E12, N10, P11

Keywords: social democracy, wage-led growth, profit-led growth, NAIRU economics, Europe 1945- , New Labor.

* This paper is written for a Festschrift in honor of Professor Amit Bhaduri. The author is very grateful to Thomas Ferguson, whose comments fundamentally improved the argument.

$\dagger$ Delft University of Technology.

https://doi.org/10.36687/inetwp122 


\section{The dilemma facing social democracy}

Social democracy, the political force that shaped post-1945 Western Europe more than any other political movement (Berman 2006; Judt 2010), is dying — or so it appears. In recent years, in European country after country, voter support for social-democratic parties, which had been hegemonic on the left, has collapsed. France's Parti Socialist, which received the support of $23.8 \%$ of the electorate in 1998 and peaked at $29.4 \%$ of voters in 2012 , won only $9.5 \%$ in the parliamentary election in 2017; it is now France's fifth-largest political party. Support for the Dutch Labor Party (PvdA) fell dramatically, if not spectacularly-from a peak of $29 \%$ of the voters in 1998 to a mere $9.2 \%$ in 2017. In Germany, voter support for the SPD dropped from almost $41 \%$ in 1998 to $20.5 \%$ in 2017 , which was its worst electoral result during the entire post-war period. Electoral support for social-democratic parties in Italy fell from 43\% in 1996 to $23 \%$ in the 2018 elections, and the Greek PASOK party polled at just over 6 percent in 2015 , down from $43.8 \%$ in 2000. Britain's Labor Party last electoral win dates back to 2005- half a generation ago. The result has been a remarkable decline in the political relevance and influence of Europe's social-democratic parties (Marlière 2010).

This decline is even more astonishing, because most voters, heavily hit by the fall-out of the 2008 global financial recession and the ensuing painful Eurozone crisis, and cognizant of the sharp increase in the gap between rich and poor, would in earlier times likely have turned to the social democrats. But the reality is, they didn't. Part of the reason is voter opposition to postcrisis austerity policy in the E.U., which was in many instances the responsibility of socialdemocratic parties participating in government. This has, without doubt, contributed to the weakening of the political Left. But there is more: the roots of the demise of social democracy stretch back further in time (Judt 2010). In fact, the beginning of its slump dates back to the 1970s (Marlière 2010). Average voting for social-democratic parties in the E.U.-12 countries was $29.7 \%$ in the $1990 \mathrm{~s}$, which was below the 1980 s average $(31.1 \%)$ and well below the $1950 \mathrm{~s}$ peak $(33.2 \%)$. The decline continued, with average electoral support for social-democratic parties in the E.U.-12 being 26.6\% during 2000-09 and dropping down to around 21\% during 2010-19. What it means is that social democracy has been steadily losing votes over the past forty years - and at an accelerating rate. While the decline in voter support was 1.5 percentage points in the 1970 s and only 0.6 percentage points in the $1980 \mathrm{~s}$, this increased to 1.9 percentage points in the 1990s, 2.6 percentage points in the early 2000s and to a loss of around 5 percentage points in the 2010s. Compared to the 1950s and 1960s, social democratic parties in the E.U.- 
12 have lost around 12 percentage points in electoral support-and in France, Greece and the Netherlands, there is not much left of the social-democratic Left.

The long-run decline of electoral support for social democracy reflects, as this paper argues, a failure of social-democratic parties in Europe to strike a convincing and effective balance between 'short-term practical relevance' and 'progressive, egalitarian reformism'. This is the inescapable dilemma facing European social democracy, as outlined by Amit Bhaduri (1993), in a brilliant, but little known contribution to a Festschrift for K.N. Raj: short-term practical relevance requires social democracy to accept, at least partly, the very socio-economic and political conditions (of 'really-existing capitalism') which it purports to change in the longer run.

The dilemma arose historically in the 19th century, as universal suffrage became a feasible goal in many parts of Europe. Universal suffrage opened up a 'parliamentary', 'gradualist' pathway to social democracy as a feasible alternative to the more bumpy 'revolutionary' road. But going down the incrementalist-parliamentary path, as Bhaduri argues, implied transforming a confrontational 'class politics' into a co-operative 'coalition politics', based on class compromises, once it became clear that no social-democratic electoral majority could be created based on just the industrial working class. Such coalition politics constituted a first check on the social-democratic project.

In addition, the rules of the game set by property-owning democracies imposed a second, even more binding, constraint on any social-democratic economic program, aiming for the nationalization of the means of production and a gradual transformation of ownership structures in general. Working within the rules of capitalism, social democracy had to abandon these goals. After all, the capitalist class has the power to strike back against attempts to nationalize the means of production by sharply reducing firm investment which, in turn, would reduce demand and employment in the short run and have negative impacts on long-run growth as well.

This then is the dilemma: social-democratic policies must at the same time strengthen the productive power of capital and counteract the (political) power of capitalists. Once the goal of systemic transformation was abandoned and the commitment was made to maintain private property of the means of production, social democrats had to work, through the state, within the 
capitalist system, assuring its efficiency and the growth of productive capabilities, while (as far as possible) mitigating adverse distributional effects. Crucially, in all this, the state is not neutral, but 'governed by its class character' and inclined to protect the 'foundations' and 'authority structure' of the capitalist order' (Kalecki 1943); to be clear, there is no 'hard' fiscal budget constraint within which social democracy had and has to formulate its political compromise, because states can borrow from (lender-of-last-resort) central banks. Rather, the 'hard' limit is based on what is deemed 'political acceptable' by national elites and establishment interests.

\section{Co-operative capitalism: the 'wage-led' compromise}

During the Great Depression of the 1930s, the twin constraints led to a drastic reorientation of European social democratic thinking: away from the "nationalization of the means of production' to the 'nationalization of consumption', as Swedish economist Bertil Ohlin (1938, pp. 4-5) put it. Reformism was abandoned - and capitalism accepted —on the condition that it be regulated and disciplined by the state, without any need to socialize the means of production (Table 1). Social democrats developed a full-fledged ideology of the 'welfare state', as the means to nationalize consumption and bring about mass-consumption-driven economic expansion. The fact is, writes Adam Przeworksi (1985, p. 36), that

'social democrats everywhere soon discovered in Keynes' ideas, particularly after the appearance of his General Theory, something they urgently needed: a distinct policy for administering capitalist economies. The Keynesian revolution - and this is what it was-provided social democrats with a goal and hence the justification of their governmental role, and simultaneously transformed the ideological significance of distributive policies that favored the working class."

The Keynesian turn was narrowed down to the argument that effective demand could be increased and unemployment reduced by redistributing income in favor of the lower-income groups (which have a higher propensity to consume).

Carried to its logical extreme, higher wages and other pro-labor policies to manage aggregate demand could be shown to benefit the capitalist class as well-at least in principle; the configuration of structural conditions which bring about this outcome of 'wage-led growth' was 
formalized by Bhaduri and Marglin (1990).1 Thus, during the 1950s and 1960s, Keynesian demand management (mostly through deficit financing of desirable lines of public spending) helped sustain a full employment regime, which featured high real wage growth, shortening of the working week, and the build-up of welfare states, but at the same time safeguarded adequate profit rates for firms, thereby offering an effective solution to the dilemma facing European social democracy (Marglin and Schor 1992; Glyn 2006).

The Keynesian consensus of the 1950s and 1960s was unusually broad, including West-German 'social market' theorists, the governing Labor Parties in Britain and the Netherlands, socialdemocratic governments in Scandinavia and Austria, as well as the 'indicative planners' who shaped French public policy during the 1950s and 1960s. Its success was historically unprecedented (Marglin and Schor 1992); as political scientist Ralf Dahrendorf (1979, pp. 1089) wrote in a post-mortem at the end of the 1970s, in "many respects the social democratic consensus signifies the greatest progress which history has seen so far. Never before have so many people had so many life chances."

A sharper economic understanding of the foundations of the 'golden age of co-operative capitalism' can be derived from a closer look at the following simple, but insightful, decomposition of the profit rate of firms $(\rho)$, defined as the real return on their invested capital:

$$
\rho=\frac{\Pi}{K}=\frac{\Pi}{X} \times \frac{X}{\bar{X}} \times \frac{\bar{X}}{K}=\pi \times u \times \kappa
$$

Here $\pi=(\Pi / X)=$ the share of real profits $(\Pi)$ in real manufacturing income $(X), u=(X / \bar{X})=$ capacity utilization, and $\kappa=(\bar{X} / K)=$ the 'normal' output-capital ratio in manufacturing. $K$ is the capital stock (at constant prices) and $\bar{X}$ is 'normal' (trend) output. I assume that $\kappa$ is a long-run constant (Storm 2019). Eq. (1) can be extended using the following definition of the profit share $\pi$ (Storm and Naastepad 2012):

1 Aggregate demand is said to be 'wage-led' if it increases in response to a rise in the real wage rate. A higher real wage will normally raise consumption demand, but lower investment and (net) exports. Investment declines, because the higher wage reduces the profit share. Net exports decline, because the higher wage raises unit labor cost of production; to the extent that this raises prices, the international cost/price competitiveness of the country will be hurt. Therefore, aggregate demand is 'wage-led' if the increase in consumption demand (due to increased wages) more than offsets the declines in investment and (net) exports. Aggregate demand is 'profit-led' if it falls in response to an increase in the real wage. See Bhaduri and Marglin (1990) and Storm and Naastepad (2012). 


$$
\pi=1-\theta=1-w \times \lambda^{-1}
$$

where $\theta=$ the wage share, $w=$ the real wage (per hour of work), and $\lambda=$ labor productivity per hour worked. Substituting (2) into (1) gives:

$$
\rho=\left(1-w \times \lambda^{-1}\right) \times u \times \kappa
$$

It can now be seen that the profit rate has three determinants: the real wage $w$, labor productivity $\lambda$, and capacity utilization $u$, which is determined by aggregate demand. Equation (3) brings out, in sharp relief, the dilemma facing social democracy: attempts to increase the real wage $w$ for the working class raise the wage share, but reduce the profit share and therefore decrease the profit rate (under the ceteris paribus assumption).

However, the 'golden age of co-operative capitalism' managed to avoid (or overcome) this profit squeeze, because of four factors which more than offset the negative impact of higher wages on the profit rate. First, aggregate demand was 'wage-led' (Bhaduri and Marglin 1992), which meant that higher wages led to higher demand and hence to higher capacity utilization; as eq. (3) shows, higher utilization $u$ raises the profit rate $\rho$ (keeping other factors constant). Second, the pressure of high wages on the profit rate was reduced, because higher demand and higher utilization led to higher labor productivity through the Kaldor-Verdoorn relation.2 In terms of eq. (3), this means that labor productivity $(\lambda)$ increases in response to higher utilization (demand), and this in turn contributes to an increase in the profit rate $(\rho)$. The third factor was that high wages were supported by fiscal policy intended to keep the economy (and $u$ ) close to full employment. The fourth and final factor was the high growth of world trade, enabled by the Bretton Woods system of stable exchange rates and limited cross-border capital mobility, which contributed to high export growth in most European economies (Marglin and Schor 1992). Fiscal policy was the critical factor, because it made possible (and stabilized) high

\footnotetext{
2 The Kaldor-Verdoorn relation states that faster growth of aggregate demand and output must cause an acceleration of productivity growth. First, demand growth allows an economy-wide deepening of the division of labor and more rapid learning-by-doing (in firms), which both are processes which eventually get reflected in higher productivity growth. Moreover, to the extent that demand growth is investment growth, the new investments result in higher labor productivity, because the newly installed equipment embodies state-of-the-art technology and is therefore more productive than older vintages of capital stock. See Storm and Naastepad $(2012,2016)$.
} 
productivity growth and hence high wage growth, helped by the overall wage-led nature of demand (Storm and Naastepad 2016).

The mechanism is illustrated in Figure 1 by the upward-sloping 'wage-led demand' curve: higher wages led to higher demand and faster economic growth as well as to higher productivity growth - and with the crucial support of fiscal support policy and high export growth, the profit rate could stay the same or even increase as wages increased along with utilization By propping up demand, fiscal policy contributed to high rates of capacity utilization and a stabilization of both the profit rate and employment. This way, the wage-led growth regime of the 'golden age' allowed social democracy to break free from the trade-off between higher wages and higher employment - allowing it to have the cake and eat it.

\section{Figure 1}

\section{A Morphology of Social Democracy}

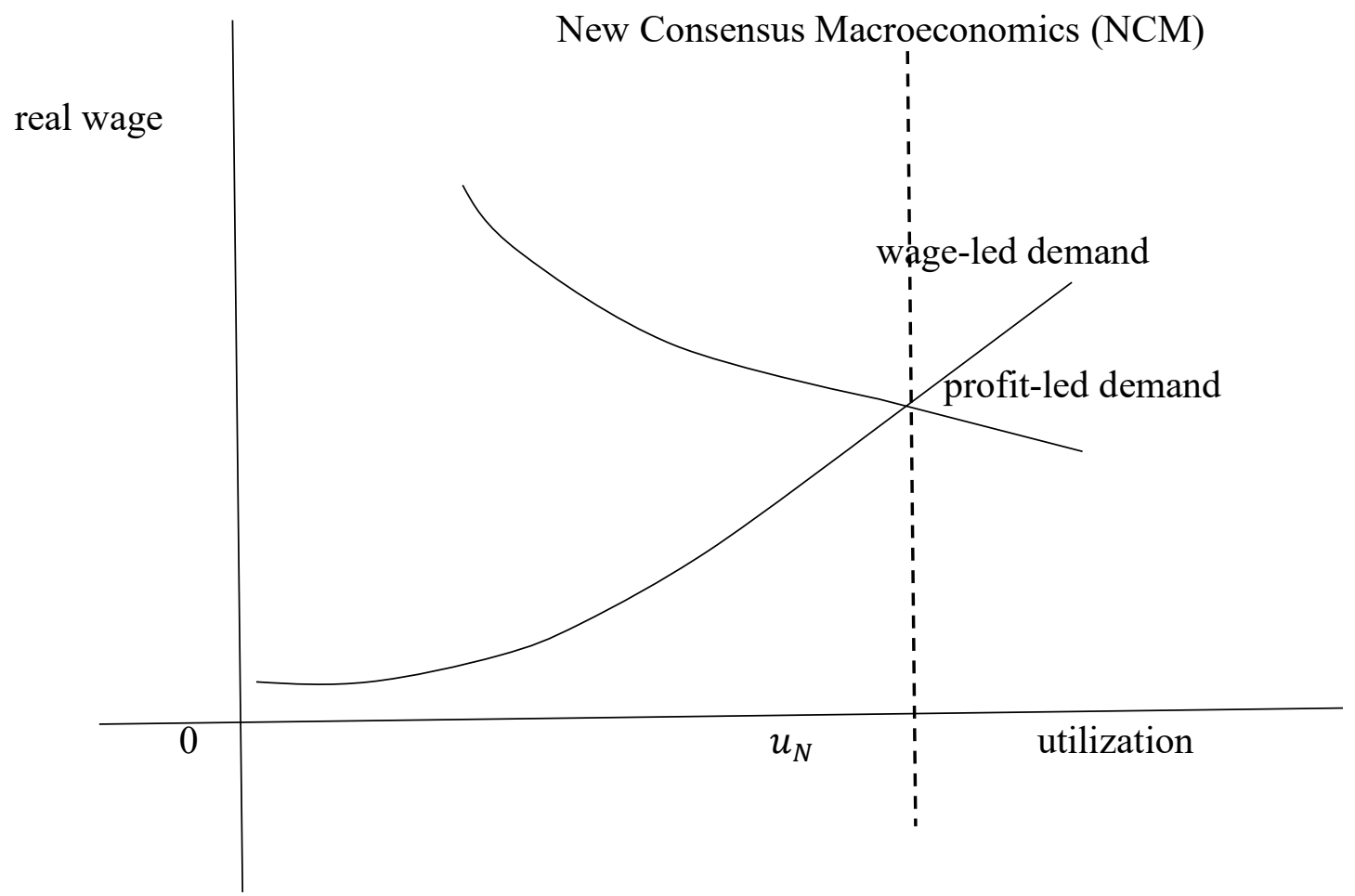

Note: $u_{N}$ is the normal (or 'steady-inflation') rate of capacity utilization.

\section{Co-operative capitalism: 'profit-led' politics}


The 'golden age of wage-led capitalism' did not prove durable, however; the compromise of the 1950s and 1960s broke down in response to the 'stagflation' of the 1970s. The reason for the breakdown was more political than economic: decades of (near) full employment had unleashed, as Michał Kalecki (1943) warned, forces which directly threatened the authority structure of capitalism - forces which became manifest in growing wage pressure, heightened worker militancy, calls for more redistribution, and growing demands for a radical democratization of society, the economy and the workplace (Glyn 2006). The breakdown of the Bretton Woods system in 1971 added further fuel to stagflation, leading to heightened uncertainty for exporters, competitive exchange rate devaluations (triggered by the devaluation of the U.S. dollar), a slowing down of world trade growth, two oil-price shocks, and importcost inflation (Halevi 2019). Demand growth began to decline, which in turn depressed productivity growth - and this drove up the wage share even more. The 'indiscipline' of workers, the collapse of the Bretton Woods order, and the consequent 'profit squeeze' led governments, which in Kalecki's view cannot remain neutral in case of escalating class conflict, to protect the capitalist order by structural policy reform aimed at improving the 'climate' for private investment and finance.

The macro-economic case for this kind of conservative-style demand management was founded on the notion of 'profit-led growth' in a Keynesian model of demand-led growth (Bhaduri and Marglin 1990; see Table 1). This regime of 'profit-led' capitalism is illustrated in Figure 1 by the downward-sloping 'profit-led' demand curve: higher wages depress aggregate demand (mostly because higher unit labor cost will reduce export and investment demand) and hence, capacity utilization declines. Higher wages hurt profitability in two ways: profits per unit of output $(\pi)$ go down and demand-determined output (and, therefore, utilization $u$ ) goes down. Accordingly, a higher $\rho$ requires that wages be reduced or that real wage growth is suppressed below the rate of labor productivity growth because this increases both the profit share and utilization. This is illustrated by the downward slope of the 'profit-led' demand curve in Figure 1, which illustrates the trade-off between higher wages, on the one hand, and higher utilization, higher profitability and higher employment, on the other hand (Esping Andersen 2000). 


\section{Table 1}

Social Democracy as a Historical Phenomenon

\begin{tabular}{|l|l|c|l|}
\hline Phases & The social-democratic consent to capitalism & Macro-economic theory & Policy focus \\
\hline c. 1890-end 1930s & $\begin{array}{l}\text { Reformism: a gradualist, parliamentary road to } \\
\text { transform capitalism into socialism }\end{array}$ & $\begin{array}{c}\text { no clearly elaborated } \\
\text { macro-economic model }\end{array}$ & $\begin{array}{l}\text { Nationalization of the economy and radical } \\
\text { redistribution of property ownership } \\
\text { structure }\end{array}$ \\
\hline end-1930s-1970s & $\begin{array}{l}\text { Keynesian demand management I: correcting } \\
\text { the outcomes of capitalism through the } \\
\text { 'nationalization of consumption' }\end{array}$ & wage-led demand & $\begin{array}{l}\text { Full-employment fiscal policy; build-up of } \\
\text { welfare states }\end{array}$ \\
\hline $1970 \mathrm{~s}-$ c. 1990 & $\begin{array}{l}\text { Keynesian demand management II: correcting } \\
\text { the outcomes of capitalism by protecting firms' } \\
\text { profitability }\end{array}$ & profit-led demand \\
f. $1990-$ present & $\begin{array}{l}\text { New Labor / Third-Way: } \\
\text { working to not just reproduce capitalism, but investment and growth } \\
\text { also to improve it by deregulation of financial } \\
\text { and labor markets and imposing fiscal } \\
\text { discipline on states }\end{array}$ & $\begin{array}{c}\text { New Consensus (NAIRU) } \\
\text { Macroeconomics }\end{array}$ & $\begin{array}{l}\text { Inflation-targeting by independent central } \\
\text { banks; fiscal policy rules and austerity; } \\
\text { labor market deregulation }\end{array}$ \\
\hline
\end{tabular}

Source: Based on Przeworski (1985), Bhaduri (1993) and Storm and Naastepad (2012). 
Given this trade-off, reviving private investment (and exports) became the focal point of a new wave of conservatism, which, championed by British Prime Minister Margaret Thatcher and U.S. President Ronald Reagan, centered on wage moderation, monetarist inflation control (instead of full-employment-oriented fiscal policy), the deregulation of labor and financial markets, privatization, (corporate) tax reductions, globalization and (accompanying) military build ups, and the scaling down of 'nanny' welfare states (Glyn 2006; Halevi 2019).

The collapse of wage-led growth and the crisis of stagflation brought back, with a vengeance, the dilemma of social democracy-in a profit-led system, profits must be protected from demand of the masses, because if profits are not 'sufficient', then eventually wages and/or employment must decline. In Karl Kautsky's (1925, p. 273) words, if “production does not continue, the entire society will perish, the proletariat included." In an open-economy profitled economy, full employment demand management and radical redistributive policies are not in the material interest of wage-earners, because they result in high wages and poor international cost competitiveness, and therefore low profitability, sluggish investment and stagnation (Przeworksi 1985).

Social democrats completely internalized this lesson. West-German Bundeskanzler Helmut Schmidt (1976), a leading European social democrat, articulated it as follows:

"The profits of enterprises today are the investments of tomorrow, and the investments of tomorrow are the employment of the day after." (Le Monde, July 6, 1976).

Schmidt's argument-that current profits are the foundation of future jobs and future improvements of material conditions of workers - became the cornerstone of the post-1970s social democratic consent of capitalism (Przeworski 1985, p. 43). While Schmidt's policy reorientation was conservative, social democracy's consent could still be justified within a system of co-operative capitalism (Bhaduri 1993). The reason is that it was still common understanding that aggregate demand mattered for profits and investment. Keynesianism was not dead yet. Social democrats could continue to argue in favor of fiscal stabilization (of the business cycle), (decent) minimum wages, collective wage bargaining, and welfare-state support for the unemployed, the disadvantaged and the elderly, because these 'Keynesian' interventions could be argued to contribute to stabilizing aggregate demand and protecting the profit rate. 
Social democratic politicians_-including Karl Schiller, the German SPD Minister of Economic Affairs, and Roy Jenkins, the British Labor President of the European Commission-were behind the creation of the European Monetary System (EMS) in 1979, a forerunner of the Euro. The EMS was intended to reduce exchange rate fluctuations within the European Economic Community (EEC), and especially block Italy from pursuing its strategy of inflation and devaluation. The EMS also provided a shield against the depreciation of the U.S. dollar (Halevi 2019). But the EMS put pressure to internally adjust on member countries having an external deficit, deflating their demand, cut imports and (arguably) raise exports. 3

Perhaps the clearest expression of this reorientation of social democracy within the EMS is the Dutch 'Polder Model' consensus on real wage restraint, carved in stone in the by now nearmythical bipartite 'Agreement of Wassenaar' (of November 1982). In exchange for higher investment, more jobs and a redistribution of work, Dutch labor unions agreed, albeit reluctantly and with qualifications (Becker 2003), to keep wage growth below productivity growth so as to reduce Dutch unit labor cost and raise net exports (and utilization $u$ in eq. (3)). Wage growth restraint was also intended to bring about a higher profit share and hence a higher profit rate (as in eq. (3)).

It is true that the Dutch Labor Party (PvdA) initially opposed the agreement (when it was not in government), but already by the late 1980s and early 1990s (while in government) it claimed ownership of the agreement for a combination of reasons which are not difficult to fathom: the threat of Thatcher-Reagan conservativism, the failure of Mitterand's flawed 'Keynesian experiment', and the fact that the agreement appeared to work. Dutch unemployment declined steeply in the 1980s and 1990s, exactly when unemployment in other E.U. countries remained high or even increased. The much publicized 'Dutch employment miracle' 4 was widely attributed to the 'exemplary' Wassenaar agreement, by observers as diverse as Olivier Blanchard (2000), The Economist (2002) and the largest Dutch labor union, the FNV (see Becker 2003).

\footnotetext{
3 Halevi (2019) provides the relevant political economy of the EMS and how it morphed into the Economic and Monetary Union (EMU).

4 Dutch unemployment was more than $11 \%$ of the labor force in 1982, or 2.1 percentage points higher than the average EU-15 unemployment rate in the same year. But by 1990, Dutch unemployment had come down to $5.1 \%$, a full 2.1 percentage points below the EU-15 unemployment rate, and it declined further to only $3.1 \%$ in 2000 , with the EU-15 unemployment rate stuck at $7.7 \%$ (Storm and Naastepad 2016).
} 
The Dutch social democrats set the example to emulate, and from the late 1980s onwards, their European comrades followed suit, choosing to co-operate to reproduce capitalism and rather drastically tone down whatever was left of their initial reformist intentions-all on the assumption that their economies were profit-led and, hence, radical redistributive policies would not be in the interest of wage-earners, whose jobs and incomes depend on firm investment and, hence, on profits.

\section{The 'Nasty Trade-Off' between growth and equality}

Social democracy's compromise with 'profit-led' capitalism broke down in the early 1990s, under the impacts of two powerful forces. The first one was the collapse of communism in the Soviet Union and much of Eastern Europe, which did unravel "the whole skein of doctrines which had bound the Left together for over a century", as Tony Judt (2010, p. 142) put it. From its origin, the social-democratic Left in Europe had projected itself as the reasonable alternative to revolutionary socialism, offering a respectable radical choice within the liberal polity-but with communism in ruins and the arrival of the 'end of history', Europe's social democracy, after already having consented to a bumbling stewardship of profit-led capitalism, had nothing distinctive to offer, except its "exhausted language" (Judt 2010, p. 144). "The worst thing about Communism is what comes after," wrote the Polish former dissident and newspaper editor Adam Michnik5 - and for Western Europe's social-democratic Left, what came after was an empty space, shorn of a clear and ideological narrative which was sufficiently different from the Christian-democratic center or from (social) liberalism.

The second force to undermine the compromise of the 1980s, no less important than the first, was the demise of Keynesianism. The victory of Thatcher-Reagan conservatism was far from inevitable and it might not have happened, as Tony Judt (2010, p. 96) argued, without a supporting intellectual revolution-one which succeeded in overthrowing the Keynesian consensus and turning 'government' into the problem, rather than the solution. This is the essence of the neoliberal turn in Europe's political formation: rather than entrusting the state, or the 'Staatsvolk' in Wolfgang Streeck's (2016) terminology, with the task to stabilize the unstable capitalist economy, the new (neoliberal) conservatism relegated to deregulated

\footnotetext{
5 Quoted in Judt (2010), p. 139.
} 
(financial) markets, or Streeck's 'Marktvolk', the task to maintain the stability of the social and political order.

Markets are supposed to do this by imposing market discipline on corporations (which is argued to happen via shareholder pressure and the stock market), on individuals and households (through their engagement in labor markets and through debts), and on governments (which arguably are being disciplined by sovereign bond markets). The emergence of the state's private creditors, the 'Marktvolk', as disciplinarians of advanced capitalist states is arguably the key characteristic of this new political formation-which intensified distributional conflict over taxes, redistribution and the repayment of the sovereign debts.

In 1981-83, European social democracy suffered a traumatic confrontation with the new neoliberal order, when Francois Mitterand, the social-democratic President of France, who was elected on the promise of Keynesian demand stimulus, capitulated as soon as bond and currency markets started to protest. If Mitterand were serious about his pledge to fight unemployment, writes Joseph Halevi (2019, p. 13), "he would have addressed the financial instability by a combination of sharp devaluations of the overvalued currency ('the Franc') and also by tightening capital controls ...' But he didn't and instead made, with remarkable speed and assiduousness, a 'tournant de la riguer' as favored by the Trésor: 'structural austerity', the outlawing of monetary financing, and 'competitive disinflation', where the latter means that nominal wage growth is deliberately suppressed below inflation-to reduce unit labor cost, arguably to boost cost competitiveness and raise the profit share of French firms. It needs no elaboration that French social democrats played major roles in the scaling up of austerity, the full marketization of sovereign debt, and competitive disinflation to policy dogma at the level of E.U. and EMU (see Halevi 2019).

In macroeconomics, the 'intellectual revolution' gave birth to the New Consensus Macroeconomics (NCM) in the 1980s. NCM rejected Keynesianism by critiquing the Phillips curve-the supposedly precise and (until circa 1970 rather) stable trade-off between unemployment and inflation, which served to complete the 'Keynesian consensus' model and offered (monetary) policymakers the analytical apparatus to explore the impacts on output, unemployment and inflation (see Storm 2018 for a review). In the NCM view, the stagflation of the mid-1970s proved that the Phillips-curve trade-off could only exist in the short run, for as long as actors in the economy were wrong about (actual and expected) inflation. In the longer 
run, once actors had learned from experience and correctly started to anticipate the rate of inflation, the NCM claims that the Phillips Curve is vertical at a given rate of unemploymentthe 'natural' rate of unemployment, also known as the non-accelerating inflation rate of unemployment (NAIRU). Accordingly, monetary policy could only affect the unemploymentinflation trade-off in the short run, but economic activity could not deviate from its 'natural' level, as determined by the NAIRU, in the long run (Storm and Naastepad 2012). Likewise, in NCM, fiscal policy cannot have permanent, long-run, impacts without causing unmanageable accelerating inflation, which would force the central bank to increase the interest rate. Higher interest rates would, in turn, crowd out private-sector investment — and unemployment would converge back to the NAIRU.6

The NCM position is illustrated in Figure 1 by the dashed vertical curve, which reflects the $\mathrm{NCM}$ assumptions that $(i)$ there is a 'natural' rate of capacity utilization, $u N$, which is determined by the NAIRU and from which the economy cannot permanently diverge when inflation is kept stable (at, say, 2\%); (ii) there exists an equilibrium unemployment rate (the NAIRU), which is higher (lower) when the labor market is more (less) strictly regulated so as to strengthen the bargaining position of workers; and hence (iii) any increase in the wage rate in excess of labor productivity growth will raise inflation, but will have no permanent effect on economic activity (captured by $u N$ ). Since fiscal policy does not-by assumption-have permanent effects on the growth of the economy, but only on inflation, it follows that it makes sense to restrict the policy space for fiscal policymakers by means of stringent fiscal policy rules. Keynesian economists became the 'laughing stock' and demand management was made anathema, as Robert E. Lucas (1980) explains in a quasi-obituary:

"Keynesian economics is dead [.....]. This is a sociological, not an economic observation, so the evidence for it is sociological. For example, you cannot find a good, under 40 economist who identifies himself and his work as 'Keynesian'. Indeed, people even take offense if referred to in this way. At research seminars, people don't take Keynesian theorizing seriously any more - the audience starts to whisper and giggle to one another. Leading journals aren't getting Keynesian papers submitted anymore."

\footnotetext{
6 In reality, the Thatcher-Reagan disinflation was done through sharp increases in interest rates and strong anti-labor policies (Marglin and Schor 1992; Glyn 2006). It took a decade or more for economies to adjust to the new policy regime - and this obvious failure to quickly adjust is difficult to square with the insistence of NCM on rational, optimizing, forward-looking behavior by economic agents.
} 
Monetary policy suffered a similar fate. In the NCM view, monetary policy cannot have permanent impacts on growth and hence it should be strictly used to control inflation; this is best done by 'politically independent' central banks, run by technocrats who follow a monetary policy rule.

There is, in this approach, only one way to structurally raise growth and permanently reduce unemployment in a non-inflationary manner, namely imposing structural reforms on the labor market, which lower the NAIRU. In terms of Figure 1, lowering the NAIRU will shift the vertical $u N$-curve to the right. The higher utilization raises the profit rate, also helped by a lower real wage, and this boosts investment and growth. This way, the NCM created the governing myth that governments and central banks should refrain from intervening actively, using fiscal and/or monetary policy instruments, to smooth short-run fluctuations or to steer the economy, but rather concentrate on creating the structural conditions for deregulated (labor) markets to grind out the 'natural' long-run equilibrium (Storm 2018).

The NCM has one profound policy message, which constitutes a radical denial of the promise of Keynesian demand management in a wage-led economy: macro-economic policy faces an inescapable trade-off between 'growth' (or 'efficiency') and 'equality' (Esping Andersen 2000). What it means in common parlance is that any policy intervention to reduce inequality, for instance by means of labor market regulation and welfare-state redistribution, carries a welfare cost, because it raises the NAIRU and hence must lower growth. Vice versa, any attempt to permanently raise economic growth means lowering the NAIRU by deregulating the labor market and downsizing the welfare state - which must raise inequality. Andrew Glyn (2006) appropriately called it the 'Nasty Trade-Off' between higher wages and more jobs —or, more generally, between economic growth and egalitarianism.

The collapse of communism deprived European social democracy from its ideological 'doppelgänger'. The death of Keynesianism left it clueless and without any effective policy levers to counteract the (political) power of capitalists. The ideological emptiness created by the collapse of communism and the demise of Keynesianism in favor of NCM was filled by 'Third Way' pragmatic compromising, strategic rebranding and technological tinkering. 


\section{New Labor: Mrs. Thatcher's finest creation .....}

The defining feature of New Labor of the 'Third Way' variety is its complete internalization of the idea that there exists an inescapable 'Nasty Trade-Off'. As a result, New Labor discarded fiscal policy activism in favor of rule-based fiscal austerity, supported (and in the case of Britain's New Labor, established) the independence of central banks (in effect, handing over the levers of monetary policy to unelected and democratically unaccountable technocrats), completely submitted to 'reactionary' financial interests (of the 'Marktvolk') by endorsing central-bank inflation targeting and deregulation of financial markets, and, in doing so, lost all sense of shared purpose. "Modern capitalism has no purpose except to keep the show going", wrote Joan Robinson (1971, p. 143), and the same could be said about New Labor.

It is often stated that New Labor is 'Thatcherism with a human face'. Mrs. Thatcher, who once called New Labor 'my finest creation', would likely have agreed. But so does Peter Mandelson, who was (before he was made a Baron) one of several key politicians involved in rebranding the British Labor Party as 'New Labor' and who held a number of Cabinet positions under Prime Ministers Tony Blair and Gordon Brown. In June 2002, Mandelson publicly stated, while addressing a select group of social-democratic luminaries including U.S. President Bill Clinton, that social democrats must recognize that, when it comes to the tactics of economic modernization, "we are all Thatcherites now":

"Globalization punishes hard any country that tries to run its economy by ignoring the realities of the market or prudent public finances. In this strictly narrow sense, and in the urgent need to remove rigidities and incorporate flexibility in capital, product and labor markets, we are all Thatcherites now." (Tempest 2002)

Prime Minister Blair could sound plausibly progressive merely by saying something positive about 'inclusive growth' or the desirability of broadly accessible public services, but the thrust of his 'Third Way' economic policies was to create a business- and finance-friendly economic environment (Osler 2002) - by means of the (semi-) privatization of public services (such as London's Underground), social dumping to attract foreign investors, tax cuts for the rich and social-benefit cuts for the (undeserving) poor, opting out of the European social charter, unconditional support for financial globalization, harsh law \& order policies and deregulation of labor and financial markets, while turning a blind eye on rising income and wealth inequality (Glyn 2006; Marlière 2010). Blair and his aides consistently used Thatcherite rhetoric to strengthen his 'New Labor' credentials, such as the use of 'No turning back' and 'No, no, no.' 
In Labor's 1997 manifesto, Blair promised, in a special business section, that "Labor is now the party for business, the entrepreneurs' champion." Business influence within the Labor Party increased as trade unions were increasingly marginalized (Osler 2002).7

But it is not just Britain's New Labor. In the 1990s, it was widely felt that European social democracy needed a modern makeover, in particular by becoming more market-friendly. As a result, Europe's social democracy became a conservative force, both politically and economically - and most national governments adopted the strategy of blaming the E.U. and Brussels for unpopular policy reforms, which they themselves were (covertly) favoring. During 1997-2002, in France, Lionel Jospin who led a coalition government of the 'gauche plurielle', privatized more public utilities than all the previous conservative governments combined (Marlière 2010); Jospin also publicly cautioned against wage increases, and a few months after his electoral victory, put his prime-ministerial signature on the Treaty of Amsterdam, which included the Growth and Stability Pact, as if he had already forgotten that he had campaigned on the promise to renegotiate the austerity inherent in the Pact. Similarly, SPD-leader Gerhard Schröder, Germany's Armani-wearing and business-friendly Bundeskanzler, often called 'der Genosse der Bosse', dismantled large parts of the German social welfare state, while deregulating the labor market with his Agenda 2010 (Odendahl 2017). In Italy, Walter Veltroni and Massimo d'Alema decimated the Left in a coalition with right-wing parties. At home and in the E.U., social-democratic parties consolidated this neo-Thatcherite consensus, promoting 'markets' and 'community' — but as party members and voters discovered they could no longer meaningfully engage with politics when and where it mattered most, they started to switch off. To illustrate: in the 2002 French presidential elections, Jospin polled third, coming behind the National Front's candidate Jean Marie Le Pen.

Again, the Dutch social democrats had arrived there first. In his famous Den Uyl Lecture of December 1995, PvdA-leader and Prime Minister Wim Kok spoke about the "liberating experience of shedding the ideological feathers" (Kok 1995). Trying to rebrand social democracy as some moderate version of Thatcherism, Kok proclaimed:

Osler (2002) documents how relations between New Labor and business were cemented through large donations to the party, often running to millions of pounds, from top executives and leading companies. Such generosity was reciprocated with peerages for major benefactors, while corporate supporters (including multinationals with questionable track records on union recognition, human rights and the environment) were given lucrative privatization contracts. 
"We no longer speak of a social-democratic 'vision' or 'the alternative' of the PvdA. [...] There is no alternative for the societal constellation we have now and therefore it's no use to aim for one." (cited in Marijnissen 2009, p. 36).

The Dutch PvdA hoisted the white flag - in an unconditional surrender to TINA that there is no escape from the 'Nasty Trade-Off'. It internalized the NCM mantra that traditional demand management by the state is no longer effective, nor can the problem of unemployment be solved by mere wage restraint. It meant that Kok felt forced to choose between 'Scylla' (protecting Dutch egalitarianism, but at the cost of low growth and high unemployment) and 'Charybdis' (promoting growth of incomes and jobs, but at the cost of greater inequality). He opted for the latter, prioritizing job growth over rising inequality.

In terms of Figure 1, job growth means that the $u_{N}$-curve has to shift to the right $-\mathrm{a}$ shift associated with a non-inflationary step-up in economic growth, brought about by a decline in the NAIRU. This required, in line with the NCM view, a drastic deregulation of labor markets, implementing labor market programm which offered positive ('carrots') and negative ('sticks') incentives pushing (more) people on to the labor market, and a considerable tightening of the access to social security systems, and pension and tax reforms (intended to incentivize working). These are thoroughly supply-side measures aimed at increasing (cheap) labor supply and raising the ease with which firms can hire and fire workers. Tellingly, the motto of the two consecutive Dutch governments (1994-2002) led by Prime Minister Kok was “jobs, jobs, jobs"- a motto he also gave to the report of the Employment Taskforce (2003), which he chaired in 2003 on behalf of the European heads of state. "Jobs, jobs, jobs" became the shared policy priority of all left-of-center governments, which in the face of historically high rates of unemployment decided to step up job growth (Bonoli 2004). These Social Democrat governments operated in the belief that fuller employment is possible only if one reduces the cost of labor and allows for low-wage flexible services jobs, as in the case of the labor market reforms of New Labor (Glyn 2006) and the Hartz-Reforms of the Schröder government (Odendahl 2016).

Table 2 presents the decline in the NAIRU (as estimated by the OECD) achieved during the rule of six New Labor governments in the E.U. The NAIRU, just to be clear, is not the actual (observed) rate of unemployment, but rather the (estimated) rate of unemployment associated with a steady-inflation growth path of the economy under consideration (see Storm and Naastepad 2012). France, Germany and Italy had much higher NAIRU's than the Netherlands, 
Sweden and the U.K. - a difference caused by the fact that their labor markets were more heavily regulated in favor of labor.

The NAIRU is supposed to be a measure of structural unemployment, which changes only slowly, if at all - and if the NAIRU goes down, this must (in NCM theory at least) reflect structural deregulatory reform of an economy's labor market. As Table 2 shows, the NAIRUs came down in these six countries, and in most cases in no small measure. Reforms by the Kokgovernments (1994-2002) contributed to a decline in the Dutch NAIRU by 2.13 percentage points. Structural labor market reforms by Blair's governments (1997-2007) lowered the British NAIRU by 1.43 percentage points (over a period of ten years), while Jospin's reforms reduced the French NAIRU by 1.24 percentage points (in only five years). But by far the biggest reduction in the NAIRU was engineered by the Schröder government in Germany: after the introduction of the Hartz reforms, Germany's NAIRU came down from a peak of $9.49 \%$ in 2004 to $6.76 \%$ in 2010 , a decline of 2.73 percentage points. The numbers in Table 2 underscore the considerable ambitions of Europe's New Labor governments.

These reforms created a larger 'disposable' labor force, a flexible reserve army of the underemployed, and through this, raised inequality. This is clear from Table 2, which also presents changes in income inequality (as measured by the Gini coefficient of household disposable income) in the six countries over (roughly) the same period of time. Income inequality clearly increased across the board (Italy is the only exception here). In NCM logic, higher inequality is the collateral damage of lower unemployment (per the 'Nasty Trade-Off') - it is something New Labor was willing to accept, and remarkably leisurely so. As Peter Mandelson put it, he "was relaxed about people getting filthy rich" (quoted in Marlière 2010). Many voters were not—and felt increasingly left behind by Labor's leadership. 
Table 2

The Trade-Off between Unemployment and Inequality

\begin{tabular}{|c|c|c|c|c|c|c|}
\hline & & & & \multicolumn{3}{|c|}{ Gini coefficients: income } \\
\hline & \multicolumn{2}{|c|}{ \%-change in the NAIRU under New Labor: } & Social-democratic & mid-1990s & 2008 & change \\
\hline France & $-1.24 \%$ & from $9.87 \%$ in 1997 to $8.63 \%$ in 2002 & Lionel Jospin (1997-2002) & 0.28 & 0.29 & 0.02 \\
\hline Germany & $-2.73 \%$ & from $9.49 \%$ in 2004 to $6.76 \%$ in 2010 & $\begin{array}{l}\text { Gerhard Schröder } \\
(1998-2006)\end{array}$ & 0.27 & 0.30 & 0.03 \\
\hline Italy & $-0.05 \%$ & from $9.48 \%$ in 1996 to $9.43 \%$ in 2001 & 'Olive Tree' governments & 0.35 & 0.34 & -0.01 \\
\hline NL & $-2.13 \%$ & from $6.87 \%$ in 1994 to $4.74 \%$ in 2002 & Wim Kok (1994-2002) & 0.25 & 0.29 & 0.04 \\
\hline Sweden & $-0.57 \%$ & from $7.49 \%$ in 1994 to $6.92 \%$ in 2006 & $\begin{array}{l}\text { Ingvar Carlsson/ } \\
\text { Göran Persson }\end{array}$ & 0.21 & 0.26 & 0.05 \\
\hline U.K. & $-1.43 \%$ & from $7.30 \%$ in 1997 to $5.87 \%$ in 2007 & Tony Blair (1997-2007) & 0.31 & 0.34 & 0.03 \\
\hline
\end{tabular}

Sources: (a) NAIRU estimates are from: OECD Economic Outlook Dataset, No. 105, May 2019;

(b) Gini coefficients of household disposable income are from: Bonesmo Fredriksen (2012).

Note: $\quad \mathrm{NL}=$ The Netherlands. During 1997-2002, social democrats were in government in 12 out of 15 E.U.

member states. 


\section{The economic consequences of New Labor}

Although New Labor's compromise did succeed in reducing unemployment, it rather spectacularly failed to improve overall macroeconomic performance. Table 3 presents growth rates of real GDP, hourly employment and (hourly) labor productivity growth in the same six European countries which appeared in Table 2. Real GDP growth during 2000-08 was considerably below growth in the 1990s in all economies listed in Table 3 (except Sweden) notwithstanding the structural reforms introduced on New Labor's brief. The reason for the growth slowdown is ironic: as is shown by study after study, aggregate demand in these six economies is robustly 'wage-led' (Storm and Naastepad 2012, 2016). This means that the New Labor strategy of wage restraint and structural reform, coupled with strict rule-based fiscal austerity (Storm 2019), which was meant to reduce the NAIRU, raise the profit rate $\rho$ and push up utilization $u$, backfired. The reason: it did reduce demand and utilization and hurt both the profit rate and investment. In terms of Figure 1, the relevant curve is not the vertical $u N$-curve, proposed by NCM, but rather the upward-sloping ('co-operative Keynesian') wage-led demand curve. To paraphrase Mark Twain, the report of the death of Keynesianism seems to have been an exaggeration.

However, the macroeconomic damage done is larger. The labor market deregulation and supply-side measures to push more people into the labor market were, as noted above, successful: unemployment came down and labor force participation went up, which was exactly the intention. But at the macro level, the slowdown of economic growth and the increase in (hourly) employment growth imply, when taken together, a decline in labor productivity growth. This is what happened, as is shown in Table 3. Labor productivity declined in all countries, and most dramatically so in Italy (from 1.35\% on average per year during the $1990 \mathrm{~s}$ to zero during 2000-08). This slowdown of productivity growth puts welfare states under growing fiscal pressure (if we rule out monetary financing).

A summary indicator of the structural change that was socially engineered by New Labor's policies, is the employment elasticity $(\eta)$, estimates of which appear in Table 3 . The employment elasticity gives the percentage increase in hours of work needed to generate an increase in real GDP of 1 percentage point. During the 1990s, the employment elasticity was negative in France, Germany, Sweden and the U.K., which suggests that total hours of work declined while GDP was growing. The Netherlands, which had turned 'New Labor' years 
before the ideological turn became commonplace, is the only country where $\eta$ is positive: to generate 1 percentage point growth of real GDP, the Dutch had to increase hours worked by 0.44 percentage points.

The picture changes drastically after New Labor's reforms did work themselves out: the employment elasticity turned positive in France, Italy, Sweden and the U.K. This constitutes a major structural break with the past decades, when working hours fell with economic growth. Due to New Labor's intervention, workers now have to work 'harder' (more hours), rather than work 'smarter' (with higher productivity and reduced hours) to generate 1 percentage point of real GDP growth. It is impossible to read this as (social and/or emancipatory) progressbecause what it reflects on the ground is the growth of low-productivity, low-pay, generally temporary 'alternative working arrangements', mostly in private services industriesarrangements which in post-Schröder Germany are often 'mini-jobs', in Italy are all fixed-term contracts (Storm 2019) and in post-Kok the Netherlands most often mean temporary selfemployment.

Table 3

Real GDP growth $\hat{x}$, Hourly Employment Growth $\hat{\ell}$,

Labor Productivity Growth $\hat{\lambda}$ and the Employment Elasticity of Growth $\eta$ : Six E.U. Countries 1990-1999 and 2000-08

\begin{tabular}{|l|c|c|c|c|c|c|c|c|}
\hline & \multicolumn{4}{|c|}{$1990-1999$} & \multicolumn{4}{c|}{$2000-2008$} \\
\hline & $\hat{x}$ & $\hat{\ell}$ & $\hat{\lambda}$ & $\eta$ & $\hat{x}$ & $\hat{\ell}$ & $\hat{\lambda}$ & $H$ \\
\hline France & 1.78 & -0.01 & 1.79 & -0.01 & 1.58 & 0.54 & 1.04 & +0.35 \\
\hline Germany & 1.81 & -0.23 & 2.04 & -0.13 & 1.37 & -0.12 & 1.49 & -0.09 \\
\hline Italy & 1.35 & 0.00 & 1.35 & - & 0.82 & 0.81 & 0.01 & +0.99 \\
\hline Netherlands & 3.08 & 1.36 & 1.72 & +0.44 & 1.96 & 0.54 & 1.42 & +0.28 \\
\hline Sweden & 1.83 & -0.23 & 2.06 & -0.13 & 2.55 & 0.55 & 2.00 & +0.22 \\
\hline UK & 2.38 & -0.18 & 2.56 & -0.08 & 2.23 & 0.42 & 1.81 & +0.19 \\
\hline
\end{tabular}

Sources: $\quad$ Storm and Naastepad (2016). Employment is measured in total hours worked; GDP is in constant prices. Employment and GDP data are from the Groningen Growth and Development Centre's total economy database. Data on real compensation per employee (GDP deflator, total economy) are from the AMECO Database. The employment elasticity $\eta$ is calculated as the ratio of employment growth and real GDP growth. 
We have reached the stage where central banks appear to worry more about the growing incidence of temp work and easily 'dismissible' workers, the fissuring of the workplace, and the rise of precarious self-employment, and the consequent stagnation of wages, than socialdemocratic parties; for instance, the Dutch central bank (DNB 2018) sounded the alarm about the growing prevalence of self-employed workers, a phenomenon that was found to have also weakened the wage bargaining power of "insider" permanent workers, who have to compete with flex-workers who cost often only 60 percent of the wage cost of a permanent worker.

The stagnation of wage-led aggregate demand and the growing job and income insecurity, characteristic of the New Labor compromise, threatened to undermine its political legitimacy. The rapid growth of deregulated financial markets provided policymakers with an opportunity to defer this threat by enabling a strong growth of private borrowing, by households and firms, to keep 'the show going' by sustaining demand. Colin Crouch (2009) calls it 'privatized Keynesianism,' and its defining feature is the dramatic increase in the system's reliance on household and corporate debt to defer distributional conflicts and continue to meet the electorate's welfare expectations.

Finally, the failed New Labor compromise has caused unmeasurable political damage. This damage comes in two forms. First, big parts of social democracy's core constituency have defected to either the more extreme Left movement or to (extreme) right-wing populist parties. There is a growing polarization in the polity - with growth on the far left and even more on the far right. In Italy, France and the U.K., this polarization has already seriously destabilized the established political system - to (as yet) unknown effect. Germany, the Netherlands and Sweden each have seen not just growing right-wing populism, but also a considerable shift of the political center and 'accepted political discourse' to the right. Governing is becoming increasingly difficult under these polarized conditions.

The other form of damage comes in more subtle ways: growing (income and wealth) inequalities have made class and status divisions more powerful, have considerably reduced (upward) social mobility, and strengthened residential segregation and segregation in education (Wilkinson and Pickett 2019). In contrast, in more equal societies, citizens trust each other, there is a greater willingness to help each other, and general attitudes to the social welfare state and taxation are more positive. As inequality rises, all this goes in reverse. Growing inequalities 
also lead to a bigger role for 'political money' to shape political decision-making (Ferguson, Jorgensen, and Chen, 2020).8 Seen this way, the recent collapse in support for social democracy is a largely self-inflicted wound-and unprecedented act of self-destruction.

\section{What is to be done?}

Social democracy learnt the wrong lessons from the stagflation of the 1970s and the failure to revive private investment and (profit-led) growth in the 1980s - and by embracing NCM thinking and internalizing the 'Nasty Trade-Off' as an inescapable feature of really-existing capitalism, it contributed to locking economies into patterns of slow growth of the real economy, driven by debt-financed spending, and rapid growth of the financial sector-featuring rising inequality, more working poor, greater income and job insecurity and declining social mobility. Europe's economies are turning into dual economies, split into a technologically dynamic high-wage (manufacturing) segment, which sheds jobs, and technologically stagnant low-wage services, operating as an employer of last resort (see Storm 2019). To see that this is not a sustainable outcome, one does not have to go back to Karl Marx, but may consult Adam Smith (1776/1976, p. 88) who famously wrote that "No society can surely be flourishing and happy, of which the far greater part of the members are poor and miserable."

So what is to be done? What sort of political-economy framework can the Left propose to explain its objectives and justify its goals? For a start, social democrats should discard the now discredited NCM thinking, and draw the right lesson from Keynes, namely that capitalism is inherently unstable and needs to be 'wisely managed' in order to become more efficient. Markets turned out to be 'bad masters', and now have to be turned into 'good servants'.

Hence, rather than having 'markets' and 'Marktvolk' act as the disciplinarians ensuring social and economic order, we need states and social organization to impose stability on unruly markets, including through imposing cross-border capital controls (when and where necessary).

\footnotetext{
8 Ferguson et al. (2020) propose a "spectrum of political money", or eight ways, all legal but difficult to trace, through which outside money shapes political decision-making. These include payments to lawyers, politicians and foundations; money spent on lobbying and think tanks; formal campaign spending; the value of stock tips to political figures and public relations spending. See also Osler (2002).
} 
Social democrats also have to understand that it makes no sense to let financial markets determine the fiscal capacity of the state-this is a fundamentally political decision which involves matching society's levels of taxation to its social (spending) ambitions and deciding on how to finance a public deficit (in case it arises). This is not a plea for Big States, nor for maximum monetary financing, but rather for meaningful deliberative democracy in which citizens have a say in politics when and where it matters most. It is a firm plea against the depoliticization of fiscal and monetary policy as well as against the corrupting influence of political money on democracy — which should have been obvious to social-democrats anyway.

Second, social democrats must reject the ideology of the 'Nasty Trade-Off' for what it is: a conservative fantasy. The vertical $u_{N}$-curve in Figure 1 does not exist (Storm and Naastepad 2012). European economies are wage-led, and this means that higher wages and progressive income redistribution do indeed improve macro-economic performance and benefit both workers and firms, especially when supported by aggregate demand management. Social democrats ought to stand for both fair real wage increases and a credible commitment in macroeconomic policymaking to full employment (rather than low inflation) — demands which do not conflict with productivity growth and profitability (if properly managed). Likewise, welfare states and protective labor market institutions must not be considered a cost and a drain, but rather constitute efficient frameworks which, by helping nations to share the costs and benefits of globalization and technological progress, make firms more flexible and raise their international competitiveness. The above is by no means a covert defensive call for a return to an idealized past (e.g. the 'golden age'), but instead it is an evidence-based diagnosis of where we are and how we got there and a recognition that there are alternatives to Thatcherism, beyond the 'Thatcherism with a human face'. Capitalism needs to be managed, and if citizens do not do it (through the political process) than 'superstar' firms, big banks, big-tech companies and billionaires will do it for us.

And lest we forget: the management of capitalism will soon become even more urgentbecause the coming fourth industrial revolution (with robotics and artificial intelligence taking away jobs on an unprecedented scale) and the looming crisis of global warming will reopen the Social Question (Judt 2010): how is a democratic society to respond to high un- and underunemployment, sharply rising inequalities in pay, wealth and social mobility, and to the mounting costs of climate damage and growing pressure from climate refugees? What can we do to share employment and how do we finance jobs in socially meaningful, but economically 
insufficiently profitable activities? What should be done to bring down carbon emissions, bring about the necessary technical progress in low-carbon forms of transportation and power generation, and step up zero-carbon renewable energy generation fast enough and in ways that ensure that the strongest shoulders carry the largest burden? Social democracy cannot leave it to 'markets' to find the answers to these burning questions-what is needed is 'social organization', collaboration, and co-ordination of decision-making within and between nations. A reinvented, self-critical social democracy, which has learned the right lessons from its own flawed history, can contribute to findings ways to respond to the challenges ahead in peaceful, equitable and inclusive ways, appropriate to varying national contexts.

However, any reimagined social democracy worth the name must begin by imposing discipline on banks and financial markets - and by domestication, turn them from the powerful overlords (who they currently are) into useful servants to the societal interest. This, in turn, requires a counter-revolution in economic thinking, one which overthrows the NCM in favor of more realistic (less utopian) and more humane approaches. NCM must be seen for what it is: stale nineteenth-century pre-Keynesian thinking, a parody of an accountant's nightmare, as John Maynard Keynes (1933) put it:

The nineteenth century carried to extravagant lengths the criterion of what one can call for short 'the financial results', as a test of the advisability of any course of action sponsored by private or by collective action. The whole conduct of life was made into a sort of parody of an accountant's nightmare. Instead of using their vastly increased material and technical resources to build a wonder city, the men of the nineteenth century built slums; and they thought it right and advisable to build slums because slums, on the test of private enterprise, 'paid', whereas the wonder city would, they thought, have been an act of foolish extravagance, which would, in the imbecile idiom of the financial fashion, have 'mortgaged the future' - though how the construction to-day of great and glorious works can impoverish the future, no man can see until his mind is beset by false analogies from an irrelevant accountancy. Even to-day I spend my time - half vainly, but also, I must admit, half successfully - in trying to persuade my countrymen that the nation as a whole will assuredly be richer if unemployed men and machines are used to build much needed houses than if they are supported in idleness. For the minds of this generation are still so beclouded by bogus calculations that they distrust conclusions which should be obvious, out of a reliance on a system of financial accounting which casts doubt on whether such an operation will 'pay.' We have to remain poor because it does not 'pay' to be rich. We have to live in hovels, not because we cannot build palaces, but because we cannot 'afford' them.

The same rule of self-destructive financial calculation governs every walk of life. We destroy the beauty of the countryside because the unappropriated 
splendors of nature have no economic value. We are capable of shutting off the sun and the stars because they do not pay a dividend. London is one of the richest cities in the history of civilization, but it cannot 'afford' the highest standards of achievement of which its own living citizens are capable, because they do not 'pay.'

If I had the power to-day, I should most deliberately set out to endow our capital cities with all the appurtenances of art and civilization on the highest standards of which the citizens of each were individually capable, convinced that what I could create, I could afford - and believing that money thus spent not only would be better than any dole but would make unnecessary any dole. For with what we have spent on the dole in England since the war we could have made our cities the greatest works of man in the world."

Where can one find a better place to start re-imagining social democracy? 


\section{References}

Becker, U. 2003. 'Competitive corporatism? National and transnational elements in the Dutch 'employment miracle'.' In H. Overbeek (ed.), The Political Economy of European Employment. London: Routlegde, pp. 154-175.

Berman, S. 2006. The Primacy of Politics: Social Democracy and the Making of Europe's Twentieth Century. Cambridge: Cambridge University Press.

Bhaduri, A. 1993. 'The economics and politics of social democracy.' In P. Bardhan, M. DattaChaudhuri and T.N. Krishnan (eds.). Development and Change. Essays in honour of K.N. Raj. Delhi: Oxford University Press, pp. 59-67.

Bhaduri, A. and S. Marglin. 1990. 'Unemployment and the real wage: the economic basis for contesting political ideologies.' Cambridge Journal of Economics 14 (4): 375-393.

Blanchard, Oliver. 2000. The Dutch jobs miracle. Available at: http://www.projectsyndicate.org/commentary/bla5/English

Bonesmo Fredriksen, K. 2012. 'Income inequality in the European Union.' OECD Economics Department Working Paper No. 952. Paris: OECD. Available at: https://dx.doi.org/10.1787/5k9bdt47q5zt-en

Bonoli, G. 2004. 'Social Democratic party policies in Europe: towards a Third Way?' In G. Bonoli and M. Powell (eds). Social Democratic Party Policies in Contemporary Europe. London: Routledge, pp. 197-213.

Crouch, C. 2009. 'Privatised Keynesianism: an unacknowledged policy regime.' British Journal of Politics and International Relations 11 (3): 382-399.

Dahrendorf, R. 1979. 'The end of the social democratic consensus.' Life Chances. Chicago: University of Chicago Press.

DNB. 2018. 'Flexibilisering van de arbeidsmarkt gaat gepaard met daling arbeidsinkomensquote.' ('Flexibilization of the labor market leads to decline in the wage share') DNBulletin, February 1, Amsterdam: De Nederlandsche Bank.

Economist, The. 2002. 'Model makers. A survey of the Netherland.' May 2nd.

Employment Taskforce. 2003. Jobs, Jobs, Jobs. Creating More Employment in Europe. Available at: http://www.ciett.org/fileadmin/templates/eurociett/docs/Kok_Report 2003 _Jobs_Jobs_Jobs.pdf

Esping-Andersen, G. 2000. 'Two societies, one sociology, no theory.' British Journal of Sociology 51 (1): 59-78.

Ferguson, T., P. Jorgenson, and J. Chen. 2020. 'How Much Can the U.S. Congress Resist Political Money? A Quantitative Assessment,' Institute for New Economic Thinking, Working Paper 109, https://doi.org/10.36687/inetwp109

Glyn, A. 2006. Capitalism Unleashed. Finance, Globalization and Welfare. Oxford: Oxford University Press.

Halevi, J. 2019. 'From the EMS to the EMU .... and to China.' Unpublished mimeo.

Judt, Tony. 2010. Ill Fares the Land. A Treatise on Our Present Discontents. London: Penguin Books.

Kalecki, M. 1943. 'Political aspects of full employment.' The Political Quarterly 14 (3): 322330 .

Kautsky, K. 1925. The Labor Revolution. London: Allen \& Unwin. 
Keynes, J.M. 1933. 'National self-sufficiency.' The Yale Review 22 (4): 755-769.

Keynes, J.M. 1936. The General Theory of Employment, Interest and Money. London: Macmillan.

Kok, W. 1995. 'We laten niemand los.' Den Uyl-Lecture, December 11.

Lucas, R.E. 1980. 'The death of Keynesian economics.' Issues and Ideas (Winter issue).

Marglin, S.E. and J.B. Schor (eds). 1992. The Golden Age of Capitalism. Reinterpreting the Postwar Experience. Oxford: Clarendon Press.

Marlière, P. 2010. 'The decline of Europe's social democratic parties.' OpenDemocracy.org 16 March. Available at: https:/www.opendemocracy.net/en/decline-of-europes-social-democratic-parties/

Marijnisen, J. 2009. Tegenstemmen. Een Antwoord op het Neoliberalisme. ('Voting Against. A Reply to Neoliberalism'). Amsterdam: L.J. Veen

Odendahl, C. 2017. 'The Hartz myth: drawing lessons from Germany.' CER Bulletin No. 115. London: Centre for European Reform.

Osler, D. 2002. Labor Party PLC. New Labor as a Party of Business. London: Mainstream Publishing.

Przeworski, A. 1985. Capitalism and Social Democracy. Cambridge: Cambridge University Press.

Robinson, J. 1971. Economic Heresies. Some Old-fashioned Questions in Economic Theory. London: Macmillan.

Smith, A. (1976/1776). An Inquiry into the Nature and Causes of the Wealth of Nations. Chicago: University of Chicago Press.

Storm, S. 2019. 'Lost in deflation. Why Italy's woes are a warning to the whole Eurozone.' International Journal of Political Economy 48, forthcoming.

Storm, S. and C.W.M. Naastepad. 2007. 'OECD demand regimes (1960-2000).' Journal of Post Keynesian Economics 29 (2): 211-246.

Storm, S. and C.W.M. Naastepad. 2012. Macroeconomics beyond the NAIRU. Cambridge, Mass.: Harvard University Press.

Storm, S. and C.W.M. Naastepad. 2016. 'Bhaduri-Marglin meet Kaldor-Marx: wages, productivity and investment.' Review of Keynesian Economics 5 (2): 4-24.

Streeck, W. 2016. How Will Capitalism End? London: Verso.

Tempest, M. 2002. 'Mandelson: we are all Thatcherites now.' The Guardian, June 10. Available at: https://www.theguardian.com/politics/2002/jun/10/labor.uk1

Wilkinson, R. and K. Pickett. 2019. The Inner Level: How More Equal Societies Reduce Stress, Restore Sanity and Improve Everyone's Well-being. London: Penguin Random House. 